\title{
MATHEMATICAL MODELING OF THE DRYING CURVES OF FOXTAIL MILLET SEEDS IN SPOUTED BED
}

\author{
L. D. do Nascimento ${ }^{a}$, \\ L. G. Corumbáb, \\ S. C. S. Rochac, \\ O. P. Taranto ${ }^{c}$, \\ C. M. L. Costa ${ }^{a}$, \\ ABSTRACT \\ In order to provide a contribution to future studies of foxtail millet \\ (Setaria italica), the drying kinetics of the seeds was investigated at \\ three different temperatures: 44,65 and $86^{\circ} \mathrm{C}$. The seeds of $S$. \\ italica with a moisture equal to $30 \%$ in dry basis were dried in a \\ conical-cylindrical spouted bed during an interval of $132 \mathrm{~min}$. \\ Some empirical mathematical models were selected to describe the \\ experimental drying kinetics data (Lewis, Henderson and Pabis, \\ Page, Diffusion approach, Midilli and Wang and Singh) and the \\ best models were chosen according to the statistical tests results \\ (coefficient of determination, mean relative percent deviation, mean \\ square root error and residue distribution), using the software \\ Statistica ${ }^{\circledR} 7.0$ and applying the Quasi-Newton method. Only the \\ decreasing rate period was observed in the drying kinetic curves, \\ indicating that the removal of moisture content was preferably by \\ the diffusion mechanism, which is a characteristic behavior of \\ fibrous products, like the agricultural products. The models of \\ Diffusion Aproach, Page and Midilli were the most suitable to \\ describe the experimental drying curves. \\ Programa de Doutorado em Engenharia de Recursos \\ Naturais da Amazônia. \\ ${ }^{\mathrm{c}}$ Universidade de Campinas \\ Faculdade de Engenharia Química \\ Avenida Albert Einstein, 500, CEP 13083-852, \\ Campinas, São Paulo, Brasil \\ Received: September 13, 2015 \\ Revised: October 13, 2015 \\ Accepted: November 09, 2015 \\ Keywords: foxtail millet, kinetic drying, spouted bed, \\ mathematical modeling
}

\section{NOMENCLATURE}

$\mathrm{D}$ mean relative percent deviation

$\mathrm{D}_{\mathrm{c}} \quad$ internal column diameter, $\mathrm{m}$

$\mathrm{D}_{\mathrm{i}} \quad$ air entry diameter, $\mathrm{m}$

e mean square root error

$\mathrm{k}$, a, b constants of mathematical models

$\mathrm{m}_{\mathrm{ss}} \quad$ particle mass after $24 \mathrm{~h}, \mathrm{~kg}$

$\mathrm{m}(\mathrm{t}) \quad$ particles mass variation in function of time, $\mathrm{kg}$

$\mathrm{R}^{2} \quad$ coefficient of determination

$\mathrm{R}^{*} \quad$ residue distribution

$\mathrm{T}$ temperature, ${ }^{\circ} \mathrm{C}$

$\mathrm{X}_{\mathrm{bs}} \quad$ moisture content in dry basis

$\mathrm{X}_{\mathrm{e}} \quad$ equilibrium moisture content, $\mathrm{kg}$ moisture/kg dry matter

$\mathrm{X}_{\mathrm{i}} \quad$ initial moisture content, $\mathrm{kg}$ moisture/kg dry matter

$\mathrm{X}_{\mathrm{R}}$ moisture ratio

$\mathrm{X}(\mathrm{t}) \quad$ moisture content at any time, $\mathrm{kg}$ moisture/kg dry matter

\section{INTRODUCTION}

The genus Setaria comprises around 100 species distributed throughout the tropics, subtropics and temperate regions, and Setaria italica is one of the most valuable species in economic terms ( http://www.prota4u.org/protav8.asp?h=M4\&t=Setari a,italica\&p=Setaria+italica, accessed 9.16.13). In Brazil foxtail millet is used for feeding animals, mainly birds (Corrêa et al., 2006), but this seed performs an important role in agriculture and food production in many developing countries due to its capacity for growing under adverse heat and limited rainfall conditions (Pawar and Machewad, 2005). Studies have demonstrated its food application, as verified by Anju and Sarita (2010) who assessed the nutritional content and the glycemic index of cookies prepared from foxtail millet flour, and found that those cookies presented lower glycemic rates when compared to cookies made only from wheat flour.

Drying is a complex operation that involves heat and mass transfer, together with others process rates, 
and its importance is to facilitate handling, to provide favorable conditions for storage, to reduce transportation costs (Mujumdar, 2006) and to obtain a product in conditions to be processed, as in the cases of food industries. Several researchers have studied the drying of seeds (Chayjan et al., 2012; Morais et al., 2013) since their moisture content reflects the seed quality. However, Soave and Moraes (1987) recommend to remember the thermal control during the seeds drying in order to avoid physiological damages that can promote changes in the internal structure and favor the attack by insects and microorganisms.

This research evaluates a series of empirical mathematical correlations to model the curves of drying kinetics of foxtail millet seeds in spouted bed, providing a contribution to future studies of this product.

\section{EXPERIMENTS}

\section{Materials}

The seeds of Setaria italica were purchased in September, 2012 at a local market of Belém, Pará, Brazil. The material was stored at a temperature of $6^{\circ} \mathrm{C}$ with relative humidity of $60 \%$ in a freezer, at Laboratory of Drying and Particle Coating, until carrying out the experiments.

\section{Equipment: Spouted Bed}

The spouted bed employed has a conicalcylindrical geometry, with a conical base with height of $0.15 \mathrm{~m}$, angle of $60^{\circ}$, air entry diameter $\left(\mathrm{D}_{\mathrm{i}}\right)$ of $0.0254 \mathrm{~m}$, internal column diameter $\left(\mathrm{D}_{\mathrm{c}}\right)$ of $0.16 \mathrm{~m}$ and column height of $0.8 \mathrm{~m}$. The experimental data necessary for constructing the fluidynamics and drying curves were measured using the experimental system showed in the Figure 1, where (1) represents the blower; (2) cooler; (3) orifice plate; (4) silica bed; (5) electrical resistances; (6) thermocouples and (7) spouted bed. Further, numbers (8), (9) and (10) are the differential manometers utilized to measure the pressure in the bed, on the orifice plate and in the line, using distillated water, carbon tetrachloride and mercury as manometric fluid, respectively. The resistance controller is represented as number (11).

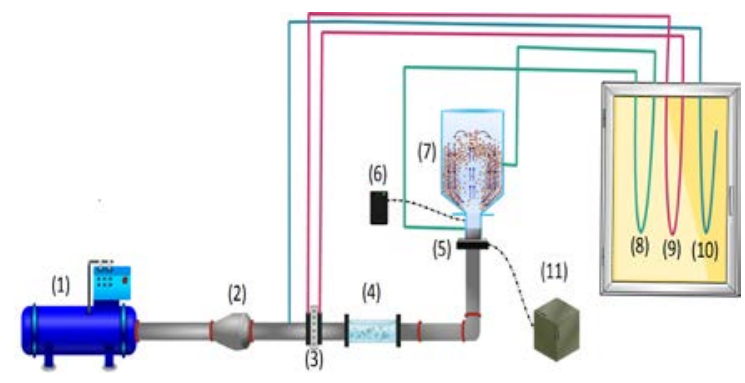

Figure 1. Experimental system.

\section{Humidification}

Since the seeds used in the experiments had a low moisture content (13.85\%), it became necessary to humidify the material, according to the following procedure: a defined volume of distilled water was sprayed on the seeds, which were revolved and subsequently stored at $6^{\circ} \mathrm{C}$. Every 24 hours, the process was repeated, completing a cycle of $48 \mathrm{~h}$ in order to achieve a moisture content of around $30 \pm$ $0.01 \%$ on a dry basis.

\section{Operation and Conditions for Drying Kinetics}

Based on preliminary studies of fluidynamic behavior, a load of $1.7 \mathrm{~kg}$ of seeds was defined for the study of drying kinetics. To obtain the experimental data, the bed was loaded with humidified seeds of foxtail millet (initial moisture content equivalent to $30 \%$ dry basis) and the air flow was adjusted in order to provide a pressure drop of $1200 \mathrm{~Pa}$ in the spouted bed with an air velocity of $0.62 \mathrm{~m} / \mathrm{s}$, the necessary conditions to ensure stable spouting during the drying process.

In this research, the drying kinetics of foxtail millet seeds was investigated at three temperatures: 44,65 and $86^{\circ} \mathrm{C}$, during an interval of $132 \mathrm{~min}$. The moisture content was determined according to the official methods of analysis (Association of Official Analytical Chemists - AOAC, 1997) at $105^{\circ} \mathrm{C}$. After the experiments, $\mathrm{X}_{\mathrm{bs}}$ (moisture content in dry basis) and $\mathrm{X}_{\mathrm{R}}$ (moisture ratio) were calculated as shown below:

$$
\begin{gathered}
\mathrm{X}_{\mathrm{bs}}=\left(\frac{\mathrm{m}(\mathrm{t})-\mathrm{m}_{\mathrm{ss}}}{\mathrm{m}_{\mathrm{ss}}}\right) \times 100 \\
\mathrm{X}_{\mathrm{R}}=\frac{\mathrm{X}(\mathrm{t})-\mathrm{X}_{\mathrm{e}}}{\mathrm{X}_{\mathrm{i}}-\mathrm{X}_{\mathrm{e}}}=\frac{\mathrm{X}(\mathrm{t})}{\mathrm{X}_{\mathrm{i}}}
\end{gathered}
$$

The Eq. (1) and Eq. (2) were used to build the drying kinetics curves, where $\mathrm{m}(\mathrm{t})$ and $\mathrm{m}_{\mathrm{ss}}$ are the particles mass variation in function of time, and particle mass after $24 \mathrm{~h}$, respectively. In Eq. (2) $\mathrm{X}(\mathrm{t}), \mathrm{X}_{\mathrm{e}}$ and $\mathrm{X}_{\mathrm{i}}$ are the moisture content at any time, equilibrium moisture content and initial moisture content, respectively.

Since that equilibrium moisture content $\left(\mathrm{X}_{\mathrm{e}}\right)$ is smaller than initial moisture content $\left(\mathrm{X}_{\mathrm{i}}\right)$ and because of variations on relative humidity of the drying air during the processes, it was adopted $X_{e}=0 \mathrm{~g} / \mathrm{g}$ on dry basis. Another authors made the same considerations, as: Sacilik (2007) and Doymaz e Pala (2003).

Some empirical mathematical models (Tab. 1) were selected to describe the experimental drying kinetics data: Lewis, Henderson and Pabis, Page, Diffusion Approach, Midilli and Wang and Singh, 
using a non-linear regression procedure to estimate the parameters associated to each model, and the best models were chosen according to the results of statistical tests (coefficient of determination, mean relative percent deviation, mean square root error and residue distribution), using the software Statistica ${ }^{\circledR}$ 7.0 and applying the Quasi-Newton method.

Table 1. Mathematical models selected to describe the foxtail millet seeds drying kinetics.

\begin{tabular}{|c|c|c|}
\hline Model & Equation & Reference \\
\hline Lewis (1921) & $\begin{array}{c}\mathrm{X}_{\mathrm{R}}= \\
\exp (-\mathrm{k} \cdot \mathrm{t})\end{array}$ & $\begin{array}{l}\text { (Kashaninejad et al., } \\
\text { 2007; Jittanit, 2011) }\end{array}$ \\
\hline $\begin{array}{l}\text { Henderson } \\
\text { and Pabis } \\
(1961)\end{array}$ & $\begin{array}{c}\mathrm{X}_{\mathrm{R}}=\underset{\mathrm{a}}{\mathrm{a} \cdot \exp (-} \mathrm{-} \\
\mathrm{k})\end{array}$ & $\begin{array}{l}\text { (Jittanit, 2011; Sousa } \\
\text { et al., 2011) }\end{array}$ \\
\hline Page (1949) & $\begin{array}{c}X_{R}= \\
\exp \left(-k \cdot t^{n}\right)\end{array}$ & $\begin{array}{l}\text { (Kashaninejad et al., } \\
\text { 2007; Vega-Gálvez et } \\
\text { al., 2010) }\end{array}$ \\
\hline $\begin{array}{l}\text { Diffusion } \\
\text { Approach } \\
\text { (1980) }\end{array}$ & $\begin{array}{c}\mathrm{X}_{\mathrm{R}}=\mathrm{a} \cdot \exp (- \\
\mathrm{kt})+(1- \\
\text { a)exp(-kbt) }\end{array}$ & $\begin{array}{l}\text { (Faria et al., 2012; } \\
\text { Perea-Flores et al., } \\
\text { 2012) }\end{array}$ \\
\hline $\begin{array}{l}\text { Midilli et al. } \\
(2002)\end{array}$ & $\begin{array}{c}\mathrm{X}_{\mathrm{R}}=\mathrm{a} \cdot \exp (- \\
\left.k t^{\mathrm{n}}\right)+\mathrm{bt}\end{array}$ & (Midilli et al., 2002) \\
\hline $\begin{array}{c}\text { Wang and } \\
\text { Singh (1978) }\end{array}$ & $\begin{array}{c}\mathrm{X}_{\mathrm{R}}=1+\mathrm{at}+ \\
\mathrm{bt}^{2}\end{array}$ & $\begin{array}{c}\text { (Sousa et al., 2011; } \\
\text { Faria et al., 2012) }\end{array}$ \\
\hline
\end{tabular}

\section{RESULTS AND DISCUSSION}

The results showed that increasing of heated air temperature favored the removal of moisture from the material, which is in agreement with the results found by other researchers (Corrêa et al., 2007; Sousa et al., 2011; Morais et al., 2013), and only the decreasing rate period was observed in the drying kinetic curves (Fig. 2), indicating that the removal of moisture content was preferably by the diffusion mechanism. Almeida et al. (2009), Mohapatra and Srinivasa Rao (2005) and Kaleemullah and Kailappan (2006) found similar results for adzuki beans, parboiled wheat and red chillies, respectively.

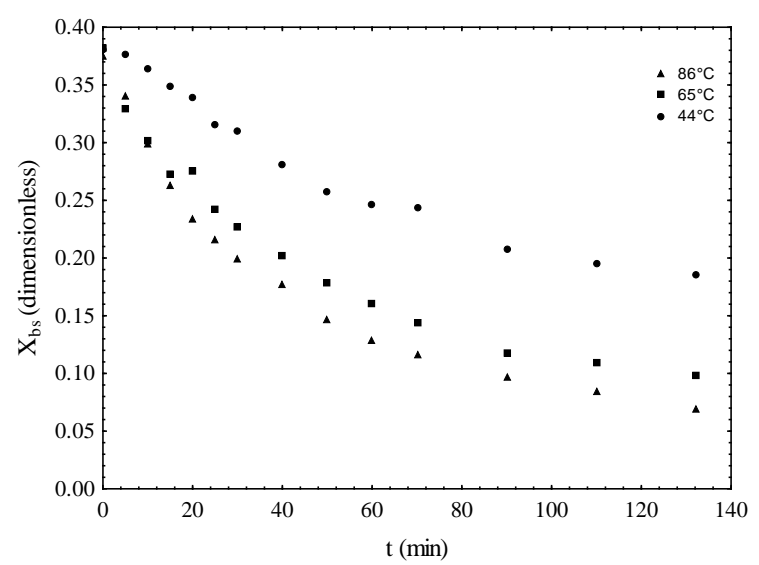

Figure 2. Drying kinetic curves of foxtail millet seed in spouted bed.
The statistical parameters were utilized to choose the most appropriate mathematical model to describe the drying kinetics, considering that the selected models should provide relative mean deviation lower than 10\% (Kashaninejad et al., 2007). All the analyzed models had coefficient of determination $\left(\mathrm{R}^{2}\right)$ greater than $96 \%$; mean relative percent deviation (D) and the mean square root error (e) lower than $10 \%$ and $0.06 \%$, respectively. On the other hand, some models did not present random residue distribution (the expected behavior), as shown in Tab. 2.

For these reasons, the selected models to describe the drying kinetics of foxtail millet seeds, at the experimental conditions of this work, were Diffusion Approach (Fig. 3), Page and Midilli, giving special attention to the former, that resulted in the best values of $\mathrm{R}^{2}$ and mean relative percent deviation.

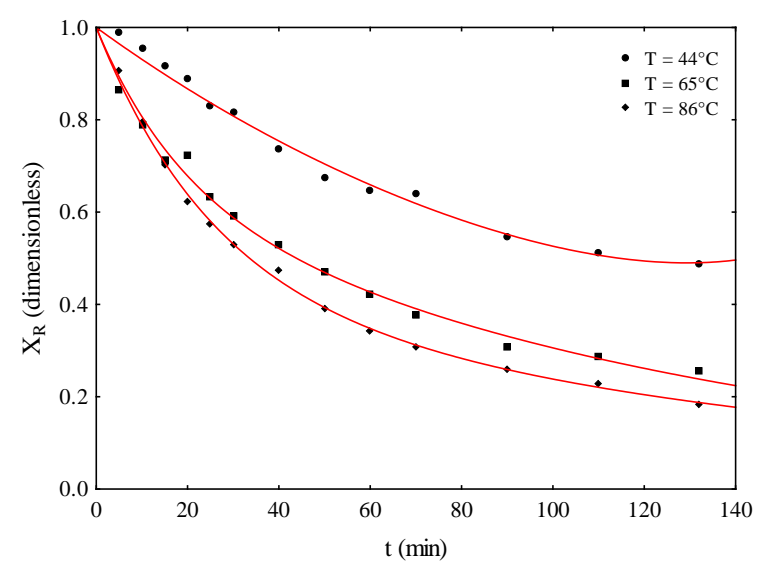

Figure 3. Experimental data fitted to the Diffusion Approach model.

Sharaf-Eldeen; Blaisdell and Hamdy (1980) proposed the Diffusion Approach model to describe ear corn drying and defined the parameters "a" and "b" as characteristics constants of product while " $k$ " was describe as a parameters that represents a function of temperature of air drying and material moisture content. It is verified from Table 2, for Diffusion Approach model, that "b" increased as the temperature elevation, but "a" and " $k$ " did not present a uniform behavior.

\section{CONCLUSIONS}

The spouted bed showed to be adequate for the drying of foxtail seeds. It was verified the absence of a constant rate during the drying kinetics, indicating that the mechanism of mass transfer was predominantly by diffusion, which is a characteristic behavior of fibrous products, like the agricultural products. 
The models of Diffusion Aproach, Page and Midilli were the most suitable to describe the experimental drying curves, mainly the former, with best results of fitting the curves.

\section{ACKNOWLEDGEMENTS}

The authors are grateful to PROPESP/FADESP (UFPA/BRAZIL) (Process 23073.004357/2014-12) and CNPq (Process 552374/2011-3) for financial support.

Table 2. Statistical parameters for the mathematical models

\begin{tabular}{|c|c|c|c|c|c|c|c|c|c|}
\hline Model & $\begin{array}{c}\text { Temperature } \\
\left({ }^{\circ} \mathrm{C}\right) \\
\end{array}$ & \multicolumn{4}{|c|}{ Parameters } & $\begin{array}{l}\mathrm{R}^{2} \\
(\%) \\
\end{array}$ & $\begin{array}{l}\mathrm{D} \\
(\%) \\
\end{array}$ & $\begin{array}{c}\mathrm{e} \\
(\%)\end{array}$ & $\mathrm{R}^{*}$ \\
\hline & & \multicolumn{4}{|c|}{$\mathrm{k}$} & & & & \\
\hline \multirow{4}{*}{$\begin{array}{l}\text { Lewis } \\
\text { (1921) }\end{array}$} & 44 & \multicolumn{4}{|c|}{0.0065} & 98.74 & 0.08 & 0.03 & $\mathrm{~A}$ \\
\hline & 65 & \multicolumn{4}{|c|}{0.0145} & 96.49 & 2.16 & 0.06 & $\mathrm{~T}$ \\
\hline & 86 & \multicolumn{4}{|c|}{0.0182} & 97.73 & 5.44 & 0.05 & $\mathrm{~T}$ \\
\hline & & $\mathrm{k}$ & \multicolumn{3}{|c|}{$\mathrm{a}$} & & & & \\
\hline \multirow{4}{*}{$\begin{array}{l}\text { Henderson } \\
\text { and Pabis } \\
(1961)\end{array}$} & 44 & 0.0064 & \multicolumn{3}{|c|}{0.9950} & 98.75 & 0.19 & 0.03 & A \\
\hline & 65 & 0.0122 & \multicolumn{3}{|c|}{0.9102} & 98.31 & 1.96 & 0.04 & $\mathrm{~T}$ \\
\hline & 86 & 0.0162 & \multicolumn{3}{|c|}{0.9341} & 98.39 & 4.39 & 0.05 & $\mathrm{~T}$ \\
\hline & & $\mathrm{k}$ & \multicolumn{3}{|c|}{$\mathrm{n}$} & & & & \\
\hline \multirow{4}{*}{ Page (1949) } & 44 & 0.0098 & \multicolumn{3}{|c|}{0.900} & 99.02 & 0.41 & 0.03 & $\mathrm{~A}$ \\
\hline & 65 & 0.0466 & \multicolumn{3}{|c|}{0.7060} & 99.73 & 0.20 & 0.02 & $\mathrm{~A}$ \\
\hline & 86 & 0.0461 & \multicolumn{3}{|c|}{0.7560} & 99.62 & 1.25 & 0.02 & $\mathrm{~A}$ \\
\hline & & $\mathrm{a}$ & $\mathrm{k}$ & & & & & & \\
\hline \multirow{4}{*}{$\begin{array}{c}\text { Diffusion } \\
\text { Approach } \\
(1980)\end{array}$} & 44 & 0.9974 & 0.0007 & \multicolumn{2}{|c|}{-3.8883} & 99.50 & 0.37 & 0.02 & A \\
\hline & 65 & 0.3441 & 0.0544 & \multicolumn{2}{|c|}{0.1409} & 99.60 & 0.18 & 0.02 & $\mathrm{~A}$ \\
\hline & 86 & 0.5606 & 0.0397 & \multicolumn{2}{|c|}{0.1654} & 99.92 & 0.05 & 0.01 & $\mathrm{~A}$ \\
\hline & & $\mathrm{a}$ & $\mathrm{k}$ & $\mathrm{n}$ & $\mathrm{b}$ & & & & \\
\hline \multirow{4}{*}{$\begin{array}{l}\text { Midilli et al. } \\
\text { (2002) }\end{array}$} & 44 & 1.0110 & 0.0065 & 1.1330 & 0.0022 & 99.75 & 0.03 & 0.02 & $\mathrm{~A}$ \\
\hline & 65 & 0.9933 & 0.0362 & 0.7973 & 0.0006 & 99.70 & 6.96 & 0.02 & $\mathrm{~A}$ \\
\hline & 86 & 1.0125 & 0.0365 & 0.8602 & 0.0008 & 99.80 & 4.31 & 0.02 & $\mathrm{~A}$ \\
\hline & & $\mathrm{a}$ & \multicolumn{3}{|c|}{$\mathrm{b}$} & & & & \\
\hline \multirow{3}{*}{$\begin{array}{c}\text { Wang and } \\
\text { Singh } \\
(1978)\end{array}$} & 44 & -0.0072 & \multicolumn{3}{|c|}{0.0000} & 99.50 & 0.38 & 0.02 & $\mathrm{~A}$ \\
\hline & 65 & -0.0143 & \multicolumn{3}{|c|}{0.0000} & 97.70 & 1.6398 & 0.05 & $\mathrm{~A}$ \\
\hline & 86 & -0.0163 & \multicolumn{3}{|c|}{0.0000} & 97.74 & 1.6091 & 0.05 & $\mathrm{~T}$ \\
\hline
\end{tabular}

\section{REFERENCES}

Almeida, D. P., Resende, O., Costa, L. M., Mendes, U. C., and Sales, J. F., 2009, Cinética de Secagem do Feijão Adzuki (Vigna angularis), Global Science and Technology, Vol. 02, No. 1 pp. 72-83.

Anju, T., and Sarita, S., 2010, Suitability of Foxtail Millet (Setaria italica) and Barnyard Millet (Echinochloa frumentacea) for Development of Low Glycemic Index Biscuits, Malaysian Journal of Nutrition, Vol. 16, No. 3, pp. 361-368.

Association of Official Analytical Chemists AOAC, 1997, Official Methods of Analysis, 16th ed. AOAC, Gaithersburg.

Chayjan, R. A., Alizade, H. H. A., and Shadidi, B., 2012, Modeling of Some Pistachio Drying Characteristics in Fix, Semi Fluid and Fluid Bed Dryer, Agricultural Engineering International, Vol. 14, No. 2, pp. 143-154.

Corrêa, P. C., Júnior, P. C. A., Ribeiro, D. M., and Silva, F. S., 2006, Modeling and Obtaining Equilibrium Moisture Content of Millet, Canary Seed and Pearl Millet, Revista Brasileira de Engenharia Agrícola e Ambiental, Vol. 10, No. 1, pp.162-167.

Corrêa, P. C., Resende, O., Martinazzo, A. N. A. P., Goneli, A. L. D., and Botelho, F. M., 2007, Mathematical Modelling for Describing the Drying Process of the Edible Bean (Phaseolus vulgaris 1.) in thin Layers, Engenharia Agrícola, Vol 27, No. 2, pp. 501-510.

Faria, R. Q. De, Teixeira, I. R., Devilla, I. A., Ascheri, D. P. R., and Resende, O., 2012, Drying Kinetics of Crambe Seeds, Revista Brasileira de Engenharia Agrícola e Ambiental, Vol 16, No. 5, pp. 573-583.

Jittanit, W., 2011, Kinetics and Temperature Dependent Moisture Diffusivities of Pumpkin Seeds During Drying, Kasetsart Journal: Natural Science, Vol. 45, pp. 147-158.

Kaleemullah, S., and Kailappan, R., 2006, Modelling of Thin-Layer Drying Kinetics of Red Chillies, Journal of Food Engineering, Vol. 76, pp. 531-537.

Kashaninejad, M., Mortazavi, A., Safekordi, A., 
and Tabil, L. G., 2007, Thin-Layer Drying Characteristics and Modeling of Pistachio Nuts. Journal of Food Engineering. Vol. 78, pp. 98-108.

Midilli, A., Kucuk, H., and Yapar, Z., 2002, A New Model for Sinlge-Layer Drying, Drying Technology, Vol. 20, pp.1503-1513.

Mohapatra, D., and Srinivasa Rao, P., 2005, A Thin Layer Drying Model of Parboiled Wheat, Journal of Food Engineering, Vol. 66, pp. 513-518.

Morais, S. J. S., Devilla, I. A., Ferreira, D. A., and Teixeira, I. R., 2013, Mathematical Modeling of the Drying Curves and Diffusion Coefficient of Cowpea Grains (Vigna unguiculata (L.) Walp.), Revista Ciência Agronômica, Vol. 44, No. 3, pp. 455463.

Mujumdar, A. S., 2006, Handbook of Industrial Drying, 3th ed., Taylor \& Francis Group.

Pawar, V. D., and Machewad, G. M., 2005, Processing of Foxtail Millet for Improved Nutrient Availability, Journal of Food Processing and Preservation, Vol. 30, pp. 269-279.

Perea-Flores, M. J., Garibay-Febles, V., Chanona-Pérez, J. J., Calderón-Domínguez, G., Méndez-Méndez, J. V., Palacios-González, E., and Gutiérrez-López, G. F., 2012, Mathematical Modelling of Castor Oil Seeds (Ricinus communis) Drying Kinetics in Fluidized Bed at High Temperatures, Industrial Crops and Products, Vol. 38, pp. 64-71.

Soave, J., and Moraes, S. A., 1987, Medidas de Controle de Doenças Transmitidas por Sementes, in: Patologia de Sementes, Fundação Cargill, Campinas, pp. 192-216. (in Portuguese).

Sousa, K. A. De, Resende, O., Chaves, T. H., and Costa, L. M., 2011, The Drying Kinetics of Forage Turnips (Raphanus sativus L.), Revista Ciência Agronômica, Vol. 42, pp. 883-892.

Vega-Gálvez, A., Miranda, M., Díaz, L. P., Lopez, L., Rodriguez, K., and Di Scala, K., 2010, Effective Moisture Diffusivity Determination and Mathematical Modelling of the Drying Curves of the Olive-Waste Cake, Bioresource Technology, Vol. 101, pp. 7265-7270. 